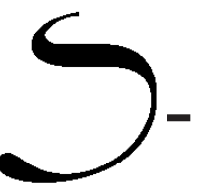

Суфиянов В.В.

\title{
Образовательная среда как условие развития системы отношений «субъект-среда»
}

Гуманистическая психология, являющаяся основой превращения образования в развивающую личность систему, считает, что самый главный источник развития человека, движущая сила находится в самом человеке. Однако для того, чтобы включились внутренние механизмы личностного роста, необходимы определенные условия. На начальных этапах развития ведущее место среди этих условий занимают условия социальные, содержащиеся во взаимодействии участников образовательной среды. Психологическую безопасность образовательной среды мы рассматриваем как важнейшее условие, позволяющее придать образовательной среде развивающий характер.

Ключевые слова: психологическая безопасность личности, психологическая безопасность образовательной среды, критерии качества образовательной среды, критерии психологической безопасности образовательной среды.

В психологии традиционного существует определенное превалирование антропоцентрического подхода, предполагающего, что все поведение человека обусловлено внутренними причинами. Так в гуманистической психологии центральная роль в формировании важнейших личностных проявлений, в том числе психологической безопасности личности, центральная роль отводится мотивам, обеспечивающим не приспособление к среде, не комфортное поведение, а рост конструктивного начала человеческого Я, целостность и силу переживания которого как раз и инициирует психологическое здоровье личности. Однако, центрация только на внутренней составляющей, очевидно, не может объяснить специфику тех компонентов проблемы психологической безопасности, которые определяются особенностями внешних воздействий, условиями внешней среды.

Среда как реальность, в которой живет человек и в значительной степени формирует ее, изучалась психологами эпизодически. Лишь во второй половине 60-х годов прошлого века возник профессионально-психологический интерес к среде, позлившему по-новому взглянуть на проблемы теоретической психологии, процессы восприятия, механизмы, «объединяющие поведение реального человека в реальном мире» ( по определению Х.Э. Штейнбах, В.И. Еленской). Исследователи среды утверждают, что человек всегда в среде, и этот фактор контакта со средой чрезвычайно важен, так как качество среды в этом случае определяет его как человека. Исследователи в средовой психологии придерживаются различных взглядов на причинно-следственные отношения «субъект-среда». Р. Баркер, основоположник школы экологической психологии, придерживается взглядов жесткого детерминизма. 
Ч. Меркер утверждает: «Поведение само по себе не может быть определенно вне контекста среды». Когнитивисты предпочитают обращать внимание на внутренние условия или прошлый опыт человека (Уно Найссер), который определяет способ реагирования. Эта виртуальная реальность не дана нам явно, и именно по этому поведение человека может казаться окружающим случайным. В наиболее современных работах отношения «субъект-среда» определяется как взаимопричинные, так как человек все время находится во взаимодействии со стимулами среды.

С позиций средовой психологии человек находится в постоянном поле взаимодействия с окружающей средой, что вызывает у него, благодаря наличию генерализованных реакций организма, определенный эмоциональный фон. В экспериментальном исследовании А.Г. Маслоу и Н.Л. Минца три группы испытуемых в разных, с точки зрения эстетического качества, средах оценивали приятность и энергичность людей, чьи фотографии им были предъявлены. Первая среда представляла собой уютно обставленный кабинет, вторая - обычную классную комнату, а третья была неприглядным техническим помещением, где держали инвентарь для уборки. Оказалось, что эстетическое качество среды существенно влияет на эмоциональную оценку. В более приятной среде лица на фотографиях оценивались значимо выше.

Для определения критериев качества образовательной среды необходимо определиться в сути понимания самого понятия «среда» в рамках психологических трактовок. В настоящий период их существует достаточно большое количество. Н. Теймур приводит порядка 40 определений понятия среды, в которых подчеркиваются те или иные аспекты проблемы. Наиболее целостные и обобщенные определения представлены Штейнбах Х.Э. и Еленской В.И.:

- $\quad$ среда - это мы. В данном определении авторы подчеркивают тот момент, что исследователи изучают средовые факторы, которые создаются самим человеком и на которые человек может оказать влияние. Типичным для данной группы определений является определение, данное Р. Соммером: «Все люди строят, создают, моделируют формы среды: мы и есть среда»;

- среда - это то, что нас окружает, все, что не мы, условия, которые влияют на нас. Дефиниции данного типа ближе к биологическому пониманию формирующей роли среды;

- $\quad$ среда - это элемент сверхсистемы. Вильден сформулировал данный подход следующим образом: «Среда - открытая система, связанная со сверхсистемой. Между ними существует обмен материей, энергией и информацией»;

- с среда - это некоторое соотношение между нами и окружением. Примером такого понимания служит определение Б. Хиллера: «Термин «среда» включает два момента - во-первых, это набор феноменов, фактов и вещей, и, во-вторых, это то, что мы переживаем. Среда, с одной стороны, - это физические факты, с другой - система человеческого опыта».

Именно это последнее определение и рассматривалось нами как исходное при трактовке базовых составляющих проблемы формирования образовательной 
среды - образовательная среда, безопасная среда, психологически-безопасная среда. Приоритет данного направления обусловлен еще и тем, что в отечественной психологии связь человека с социальной средой рассматривается как обязательный и основной фактор становления человека как личности (Л.С. Выготский, Д.А. Брудный, Д.А. Леонтьев, В.А. Петровский, С.Л. Рубинштейн). Это соответствует также подходу И.А. Баевой, по словам которой: «гуманистическая психология, являющаяся основой превращения образования в развивающую личность систему, считает, что самый главный источник развития человека, движущая сила находится в самом человеке. Однако для того, чтобы включились внутренние механизмы личностного роста, необходимы определенные условия. На начальных этапах развития ведущее место среди этих условий занимают условия социальные, содержащиеся во взаимодействии участников образовательной среды. Психологическую безопасность образовательной среды мы рассматриваем как важнейшее условие, позволяющее придать образовательной среде развивающий характер».

Поскольку человек существо социальное, именно свойства внешней социальной среды формируют качества личности растущего человека. Человек присваивает свойства окружающей социальной среды, культуры, врастая в нее, - развитие ребенка идет посредством интериоризации культуры. Но наряду с процессом интериоризации очень важен и противоположно направленный процесс - индивидуализации. Человек не только объект различных воздействий, но и субъект, который, творчески изменяя внешнюю среду, проявляет свою неповторимую индивидуальность, изменяет посредством этого собственную личность. 